Article

\title{
Biodegradation of Cosmetics Products: A Computational Study of Cytochrome P450 Metabolism of Phthalates
}

\author{
Fabián G. Cantú Reinhard ${ }^{(D)}$ and Sam P. de Visser* \\ Manchester Institute of Biotechnology and School of Chemical Engineering and Analytical Science, \\ The University of Manchester, 131 Princess Street, Manchester M1 7DN, UK; \\ fabian.cantureinhard@postgrad.manchester.ac.uk \\ * Correspondence: sam.devisser@manchester.ac.uk; Tel.: +44-161-306-4882
}

Received: 10 October 2017; Accepted: 7 November 2017; Published: 12 November 2017

\begin{abstract}
Cytochrome P450s are a broad class of enzymes in the human body with important functions for human health, which include the metabolism and detoxification of compounds in the liver. Thus, in their catalytic cycle, the P450s form a high-valent iron(IV)-oxo heme cation radical as the active species (called Compound I) that reacts with substrates through oxygen atom transfer. This work discusses the possible degradation mechanisms of phthalates by cytochrome P450s in the liver, through computational modelling, using 2-ethylhexyl-phthalate as a model substrate. Phthalates are a type of compound commonly found in the environment from cosmetics usage, but their biodegradation in the liver may lead to toxic metabolites. Experimental studies revealed a multitude of products and varying product distributions among P450 isozymes. To understand the regio- and chemoselectivity of phthalate activation by P450 isozymes, we focus here on the mechanisms of phthalate activation by Compound I leading to O-dealkylation, aliphatic hydroxylation and aromatic hydroxylation processes. We set up model complexes of Compound I with the substrate and investigated the reaction mechanisms for products using the density functional theory on models and did a molecular mechanics study on enzymatic structures. The work shows that several reaction barriers in the gas-phase are close in energy, leading to a mixture of products. However, when we tried to dock the substrate into a P450 isozyme, some of the channels were inaccessible due to unfavorable substrate positions. Product distributions are discussed under various reaction conditions and rationalized with valence bond and thermodynamic models.
\end{abstract}

Keywords: enzyme mechanism; enzyme catalysis; density functional theory; hydroxylation; epoxidation; iron(IV)-oxo

\section{Introduction}

Phthalates are commonly used chemicals in a variety of products including cosmetics. Although no clear evidence exists, they actually may be harmful compounds to biosystems and, for instance, may lead to breast cancer in humans. It is believed that phthalates can be biodegraded in the human liver and most likely cytochrome P450s are involved in this process. However, as some of these products may be toxic metabolites, and their origin is unclear, we decided to do a computational study on the most likely products obtained from the reaction of a P450 active site model with a phthalate substrate. Cytochrome P450 enzymes are a superfamily of heme-containing monoxygenases found in most biological systems, including mammals, insects and fungi as well as bacteria [1-6]. It is believed to be the most abundant enzyme family in the plant kingdom [7]. As of 2017, there have been over 39,400 sequences assigned across 236 species [8], and with many genomes yet to be sequenced, these numbers are projected to increase significantly over the next few years [6,7]. 
The P450s display a large range of substrate activation reactions and hence, they are well studied, and applications of these enzymes are being sought in biotechnology and medicine. Structurally, the P450s are heme enzymes that bind molecular oxygen on the heme iron and their most common reaction mechanism with substrates happens through oxygen atom transfer to substrates [3,9-11]. Figure 1 displays the active site structure of $\mathrm{P} 450$, as taken from the $4 \mathrm{~L} 40$ protein databank (pdb) file [12]. The resting state of $\mathrm{P} 450$ enzymes has an iron(III)(heme)(water) with the metal in a six-coordination ligand environment that is linked to the protein backbone through a chemical bond of the iron with the sulfur atom of a cysteinate residue $\left(\mathrm{Cys}_{365}\right)$. The pdb file also contains the substrate-i.e., a linear fatty acid - that is located in a pocket on the distal side of the heme and held in position through a salt-bridge with an active site Arg residue.

Upon the substrate entering into the binding pocket and approaching the heme, the catalytic cycle (right-hand side of Figure 1) is triggered through the release of the water molecule from iron and resulting in a spin state change that prompts an electron transfer from the P450 reduction partner. Subsequently, molecular oxygen binds to the heme, is reduced and protonated to form an iron(III)-hydroperoxo species, called Compound 0 (Cpd0) [13]. A final protonation step leads to an iron(IV)-oxo heme cation radical species called Compound I (CpdI). The latter reacts with substrates, for instance, through an aliphatic hydroxylation reaction via hydrogen atom abstraction followed by $\mathrm{OH}$ transfer [14]. Experimental evidence for this catalytic cycle comes from spectroscopy (UV-Vis absorption, electron paramagnetic resonance and Mössbauer spectroscopy) studies that have characterized P450 CpdI [15] as well as Cpd0 [16]. The sole oxidant of P450 enzymes is CpdI. A range of experimental and computational studies have ruled out Cpd0 as an oxidant [17-19] (i.e., iron(III)-hydroperoxo), although recent studies on biomimetic nonheme iron(III)-hydroperoxo models have shown reactivity with arenes and halides [20-22]. These differences were assigned as resulting from differences in the $\mathrm{O}-\mathrm{O}$ bond cleavage patterns between heme and nonheme iron(III)-hydroperoxo systems, where the hemes give favorable heterolytic cleavage and the nonhemes homolytic cleavage. Computational modelling has revealed that CpdI has two close-lying spin states, namely doublet and quartet spin, that are close in energy and hence the structure and reactivity is dependent on the abundances of both spin states.
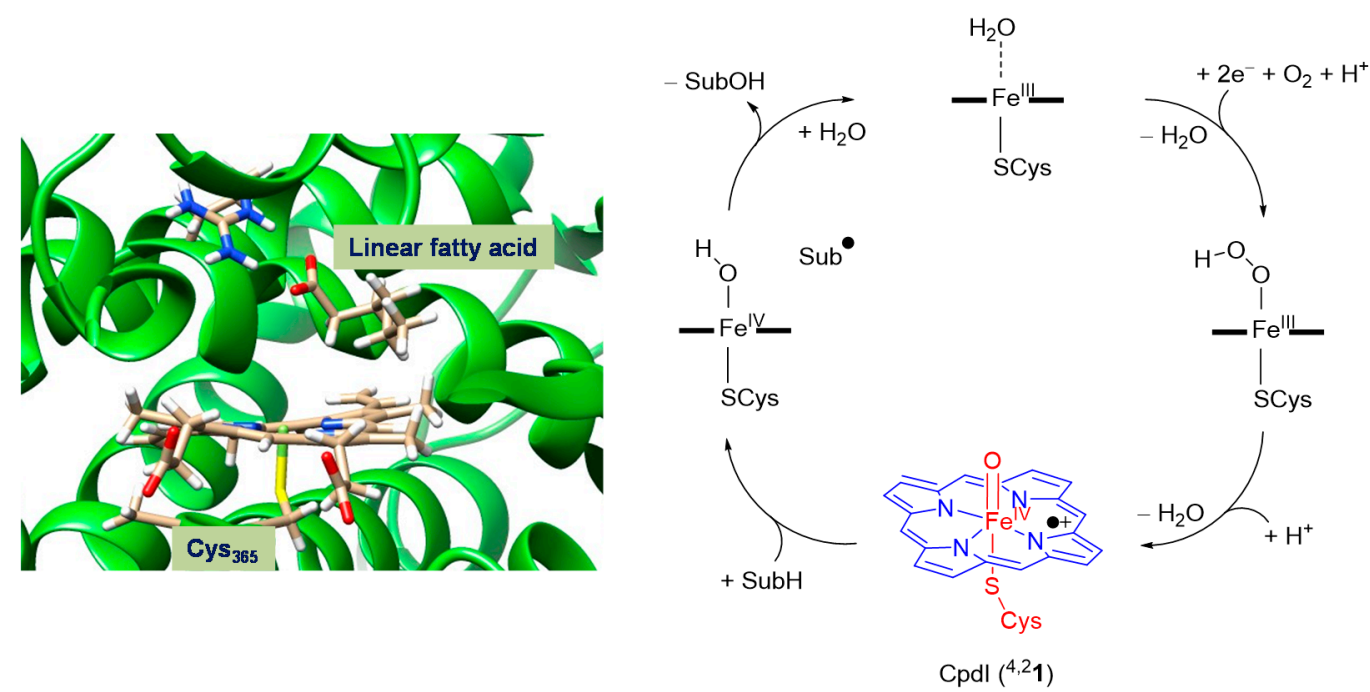

Cpdl $\left({ }^{4,2} \mathbf{1}\right)$

Figure 1. Active site structure of the substrate-bound, resting state of P450 as taken from the $4 \mathrm{~L} 40$ protein databank ( $\mathrm{pdb}$ ) file and an extract of the catalytic cycle of P450 enzymes.

The mechanism of these oxygen atom transfer reactions has been studied in detail, with a range of computational techniques [14,23]. An overview of commonly catalyzed reactions by $\mathrm{P} 450$ isozymes is given in Figure 2. The most extensively studied reaction pathway is aliphatic hydroxylation [24-27], 
which happens via a stepwise mechanism with an initial hydrogen atom abstraction to form an iron(IV)-hydroxo intermediate, followed by $\mathrm{OH}$ transfer-also called rebound-to the radical to give the alcohol product complexes. With most substrates, the hydrogen atom abstraction step is rate-determining, while the rebound barrier is much smaller [28]. In particular, the doublet spin state mechanism tends to have negligible rebound barriers, while they are generally higher on the quartet spin state surface. This is due to electron transfer into a virtual orbital in the quartet spin-state, whereas the electron can move into a lower lying orbital in the doublet spin state. P450s are also known to convert $C=C$ double bonds into olefins [29-32], sulfides into sulfoxides [33-35] and arenes into phenols [36-39] (pathways II, III and IV in Figure 2). Apart from sulfoxidation, which is a concerted process, all other oxygen atom transfer reactions are stepwise, via at least one intermediate that is usually a radical.



Figure 2. Reaction mechanisms catalyzed by P450 Compound I.

In recent years, however, alternative mechanisms have been established, which lead to desaturation or ring-closure processes (pathways V, VI and VII in Figure 2). In particular, ring-closure reactions are part of the natural product biosynthesis of antibiotics and hormone compounds [40]. Other forms of desaturation processes refer to the conversion of aliphatic groups to olefins (pathway V) or the decarboxylation of fatty acids to terminal olefins (pathway VI). Thus, desaturation reactions have been observed in the activation of drug molecules, for instance in ethylcarbamate and valproic acid, by P450 isozymes [41,42] but also in the biosynthesis of ergosterol in the human body [43]. Computational studies on the mechanism of substrate desaturation showed these desaturation reactions by CpdI to start with a hydrogen atom abstraction, similar to aliphatic hydroxylation. However, in contrast to rebound of the $\mathrm{OH}$ group to the radical, as happens in substrate hydroxylation mechanisms, in desaturation processes a second hydrogen atom abstraction by the iron(IV)-hydroxo group gives iron(III)-water and an olefin product [44,45]. As such, the mechanism can bifurcate in the radical intermediates, which can lead to both hydroxylation and desaturation products. 
Recently, a P450 isozyme was discovered (P450 $0_{\text {OleTJE }}$ ) that binds long-chain fatty acids and converts them to terminal olefins through a decarboxylation reaction [46,47]. A detailed quantum mechanics/molecular mechanics (QM/MM) study on the mechanisms leading to decarboxylation and $\alpha$ - and $\beta$-hydroxylation of the linear fatty acid was performed [48] and gave insight into the origins of the bifurcation pathways.

Clearly, P450 enzymes react via a diverse set of chemical reactions with substrates and the origins of the product distributions are not always clear. A group of substrates with great relevance for human health and excessively present in the environment is the phthalates. Experimental studies using a range of $\mathrm{P} 450$ isozymes, however, have found a mixture of products, with product ratios dependent on the isozyme [49]. Although, $\mathrm{C}^{5}$ hydroxylation was commonly observed in most P450 isozymes, in some of them significant amounts of $\mathrm{O}$-dealkylation and aromatic hydroxylation products were also obtained. To gain insight into how $\mathrm{P} 450$ enzymes metabolize phthalate substrates, we decided to do a computational study to investigate the mechanisms leading to $\mathrm{C}^{5}$-hydroxylation, O-dealkylation, and aromatic ring epoxidation and hydroxylation, which are presented in this work.

\section{Results}

Following previous benchmark and calibration studies, we started the work with enzyme active site model complexes of P450 CpdI with the substrate [50-52]. The model (see Figure 3) contained the iron(IV)-oxo group embedded in a porphyrin without side chains, while the axial cysteinate ligand was abbreviated to $\mathrm{SH}^{-}$. As a model substrate, we investigated the ester of phthalate with 2-ethylhexanol ( $\mathrm{SubH}$ ) and studied the mechanisms leading to aliphatic hydroxylation, O-dealkylation, epoxidation and aromatic hydroxylation, which are suggested products obtained for the reaction of phthalates with P450s [49]. Specifically, we focused on aliphatic hydroxylation at the $C^{5}$ position of the alkyl chain of the substrate and expected it to start with a hydrogen atom abstraction (via transition state $\mathrm{TS}_{\mathrm{A}}$ ) to give the radical intermediate, IA [24-27,53-56]. Radical rebound (via transition state $\mathrm{TS}_{\text {rebA }}$ ) would then give the alcohol product complex (PA). The mechanism tested for O-dealkylation started with a hydrogen atom abstraction from atom $\mathrm{C}^{1}$ (via transition state $\mathrm{TS}_{\mathrm{B}}$ ) to give the radical intermediate, IB. Subsequently, radical rebound (via transition state $\mathrm{TS}_{\text {rebB }}$ ) gave the alcohol product (structure IB2). In the latter, transfer of the alcoholic proton to the carboxylate group, splits substrate into a phthalate and an aldehyde (product $\mathrm{PB}$ ) via a dealkylation transition state $\mathrm{TS}_{\text {dealk. }}$. The third mechanism tested was epoxidation of the aromatic ring, where an electrophilic attack of the oxo-group on one of the aromatic carbon atoms takes place (via transition state $\mathrm{TS}_{\mathrm{C}}$ ) to form an intermediate, IC. A ring-closure transition state $\left(\mathrm{TS}_{\mathrm{rcC}}\right.$ ) then leads to the epoxide product complex, PC. The final mechanism was aromatic hydroxylation, which also starts with an electrophilic attack of the oxo-group on one of the aromatic carbon atoms (via the same transition state $\mathrm{TS}_{\mathrm{C}}$ ) to form an intermediate, IC. However, a bifurcation of the latter leads to the loss of its ipso-proton to the porphyrin ring and generates the protonated porphyrin intermediate, ID, which reshuttles its proton to the oxygen atom via a proton-transfer transition state $\mathrm{TS}_{\mathrm{PT}}$, to form phenol products (PD).

In the next few sections, we will discuss each of these mechanisms in detail, but first we will start with a comprehensive analysis of the structure and electronic configuration of the reactant complex, namely CpdI. 


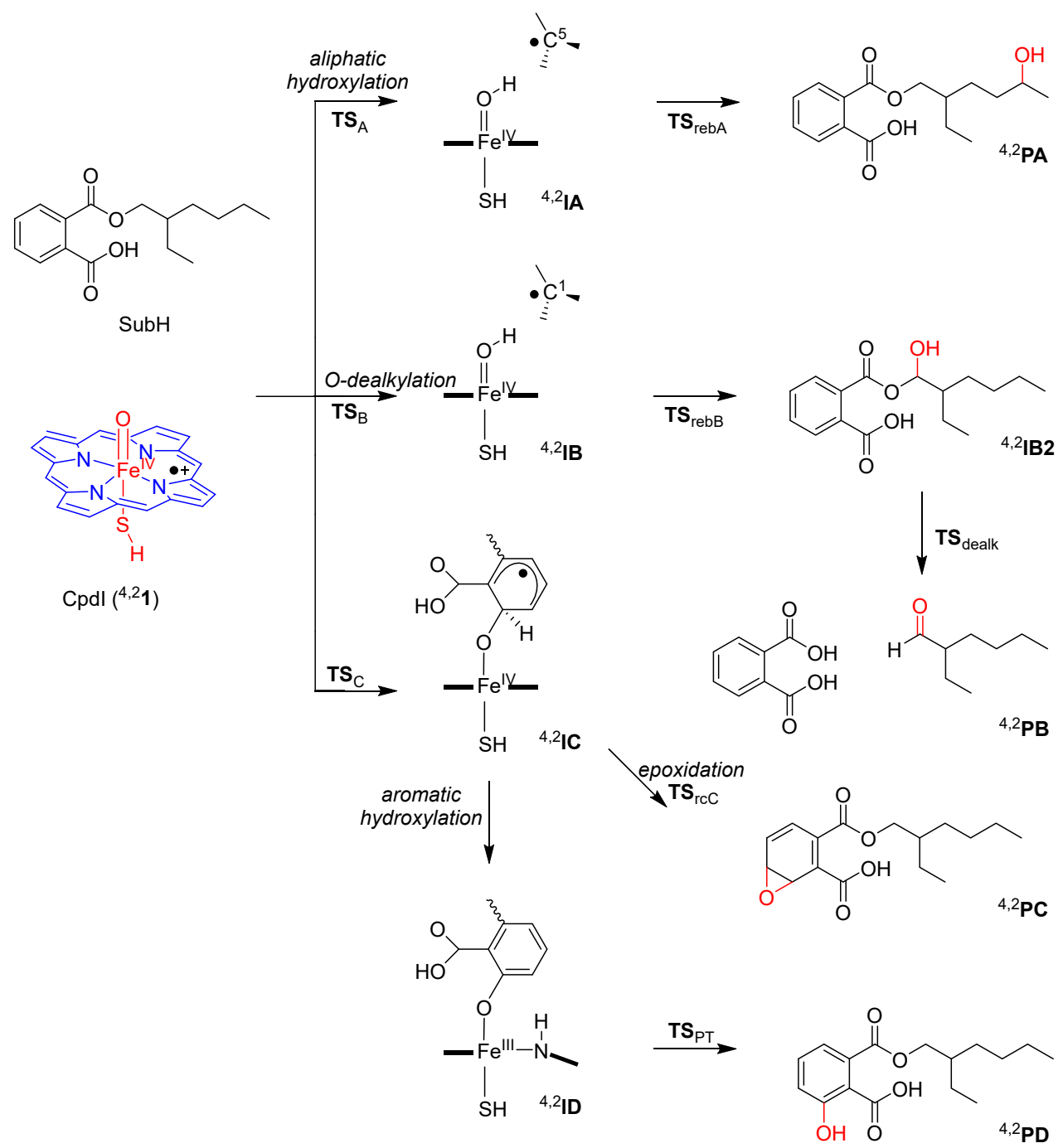

Figure 3. P450 model and reaction mechanisms (with nomenclature) studied in this work.

\subsection{CpdI Structure and Electronic Configuration}

CpdI has been characterized experimentally as a triradical system with unpaired electrons on the iron(IV)-oxo and heme groups in an antiferromagnetic manner [15]. Early density functional theory (DFT) calculations [50,51,57] as well as subsequent QM/MM studies [58-60] have predicted this electronic configuration already, but have shown that CpdI has close-lying doublet and quartet spin states of almost equal energy. Figure 4 displays the relevant valence orbitals of P450 CpdI. The left-hand side of Figure 4 gives the metal dominated molecular orbitals. The lowest three orbitals shown are the bonding-type orbitals along the $\mathrm{Fe}-\mathrm{O}$ bond and include the $\sigma_{z}{ }^{2}$ for the overlap of $3 \mathrm{~d}_{z}{ }^{2}$ on iron with $2 \mathrm{p}_{z}$ on oxygen and the degenerate pair of $\pi_{x z}$ and $\pi_{y z}$ molecular orbitals for the bonding interaction between the $3 \mathrm{~d}_{x z}\left(\right.$ or $3 \mathrm{~d}_{y z}$ ) on iron with the $2 \mathrm{p}_{x}$ (or $2 \mathrm{p}_{y}$ ) atomic orbital on oxygen. The antibonding combinations of this pair of orbitals $\left(\pi_{x z}^{*}\right.$ and $\pi^{*} y z$ ) are higher in energy and both are singly occupied. In between these two pairs of orbitals is the doubly occupied $\delta_{x}{ }^{2}-y^{2}$ orbital, which is non-bonding and located in the plane of the heme/porphyrin. The two $\sigma^{*}$ antibonding orbitals are high in energy and virtual-one along the $\mathrm{O}-\mathrm{Fe}-\mathrm{S}$ axis (the $z$-axis), namely $\sigma^{*}{ }^{2}$, and the other one in the plane of the porphyrin ring for the antibonding interactions of the metal with $2 \mathrm{p}_{x} / 2 \mathrm{p}_{y}$ orbitals on the nitrogen atoms of the porphyrin $\left(\sigma^{*} x y\right)$. Note that in this nomenclature, we took the $x$-and $y$-axis through an $\mathrm{Fe}-\mathrm{N}$ bond. If the $x$ - and $y$-axis instead are drawn in between two $\mathrm{Fe}-\mathrm{N}$ bonds, the nomenclature will change and the labels $x y$ and $x^{2}-y^{2}$ are swapped. 
On the right-hand side of Figure 4 are two high-lying $\pi$-orbitals on the porphyrin manifold, namely $a_{1 u}$ and $a_{2 u}$. The $a_{2 u}$ orbital has electron density on the porphyrin nitrogen atoms as well as the meso-carbon atoms. As a result of this, the $\pi$-orbitals can interact with the axial ligand orbitals and in particular, the $\mathrm{a}_{2 \mathrm{u}}$ mixes with a $\pi$-orbital on sulfur $\left(3 \mathrm{p}_{z}\right)$, which destabilizes the $\mathrm{a}_{2 \mathrm{u}}$ orbital in energy [61]. Consequently, the $\mathrm{a}_{2 \mathrm{u}}$ is high-lying and is easier to reduce in the absence of an axial ligand, resulting in a low electron affinity for P450 CpdI [62].



Figure 4. Relevant molecular orbitals of P450 CpdI and orbital occupation in the quartet and doublet spin-states.

Our optimized geometries of ${ }^{4,2} \mathrm{CpdI}$ match previous structures well, with $\mathrm{Fe}-\mathrm{O}$ distances of 1.626 (1.624) $\AA$ and Fe-S distances of 2.570 (2.581) $\AA$ for ${ }^{4} \mathbf{1}\left({ }^{2} \mathbf{1}\right)$, respectively. Both structures corresponded to an electronic configuration of $\pi_{x z}{ }^{2} \pi_{y z}{ }^{2} \delta\left(x^{2}-y^{2}\right)^{2} \pi_{x z}^{*} \pi^{*} y z{ }^{1} \mathrm{a}_{1 \mathrm{u}}{ }^{2} \mathrm{a}_{2 \mathrm{u}}{ }^{1}$, whereby the unpaired $\mathrm{a}_{2 \mathrm{u}}$ electron is in an up-spin state in the quartet spin state, but a down-spin state in the doublet spin state. Energetically, the two spin states are within $1 \mathrm{kcal} \cdot \mathrm{mol}^{-1}$ but their exact ordering and energy differences are dependent on whether solvent, entropy and external perturbations are taken into account $[51,61]$.

\subsection{Phthalate Hydroxylation}

Next, we investigated the reaction mechanism of aliphatic hydroxylation at the $\mathrm{C}^{5}$ position and the obtained potential energy profile is given in Figure 5. The reaction is stepwise via a radical intermediate leading to alcohol products in a highly exothermic process. The hydrogen atom abstraction barrier is rate-determining with values of $\Delta E+\mathrm{ZPE}=19.9(18.2) \mathrm{kcal} \cdot \mathrm{mol}^{-1}$ on the quartet (doublet) spin states. The imaginary frequency for the hydrogen atom abstraction barriers are large (i1750 and i1549 
for ${ }^{4} \mathrm{TS}_{\mathrm{A}}$ and ${ }^{2} \mathrm{TS}_{\mathrm{A}}$, respectively), which is typical for hydrogen atom abstraction barriers [62-65] and usually means they are affected by replacement of hydrogen by deuterium, which gives a large kinetic isotope effect [66].

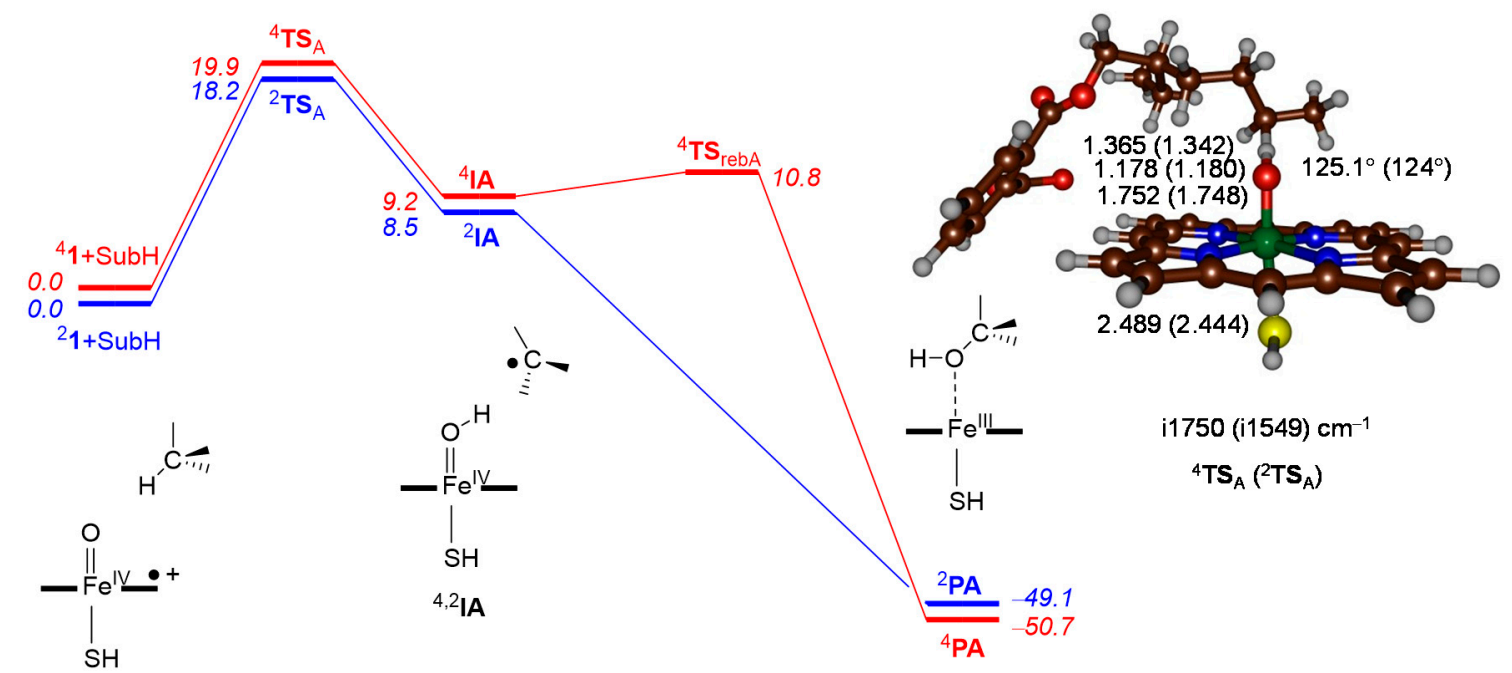

Figure 5. Potential energy landscape (B3LYP/BS1 optimized) of phthalate hydroxylation by $\mathrm{P} 450 \mathrm{CpdI}$ at the $\mathrm{C}^{5}$ position. Relative energies contain zero-point corrections and are taken from B3LYP/BS2/ / B3LYP/BS1 in $\mathrm{kcal} \cdot \mathrm{mol}^{-1}$. Optimized geometries give bond lengths in angstroms, the $\mathrm{Fe}-\mathrm{O}-\mathrm{C}$ angle in degrees and the imaginary frequency in the transition state in $\mathrm{cm}^{-1}$.

The optimized geometries of ${ }^{4,2} \mathrm{TS}_{\mathrm{A}}$ put the transferring hydrogen atom close to the acceptor oxygen atom (1.178 and $1.180 \AA$ for ${ }^{4} \mathrm{TS}_{\mathrm{A}}$ and ${ }^{2} \mathrm{TS}_{\mathrm{A}}$, respectively) indicating that the transition states are late on the potential energy surface. In general, late transition states correspond with higher barriers on the potential energy surface than earlier transition states in agreement with lower barriers [26]. In both cases a radical intermediate is formed, and spin density starts to accumulate on the substrate $\mathrm{C}^{5}$ atom ( $\rho_{\mathrm{SubH}}$ is 0.98 and 0.77 for the quartet and doublet spin states). At the same time the spin density on the $\mathrm{FeO}$ group is polarized toward iron. Formation of the radical intermediates is energetically costly and is overall endothermic by 9.2 and $8.5 \mathrm{kcal} \cdot \mathrm{mol}^{-1}$ in the quartet and doublet spin states. In the hydrogen atom abstraction step, in analogy to previous work [14,24-26,67-69], the doublet and quartet spin state surfaces are close in energy and virtually degenerate. After the radical intermediate, however, the two pathways bifurcate and a radical rebound barrier of $1.6 \mathrm{kcal} \cdot \mathrm{mol}^{-1}$ needs to be crossed on the quartet spin state surface whereas the mechanism is barrierless on the low-spin surface. Attempts were made to find a rebound transition state on the doublet spin state surface, but all our geometry scans showed facile pathways with barriers less than $1 \mathrm{kcal} \cdot \mathrm{mol}^{-1}$ to form product complexes. The overall reaction leading to alcohol products is highly exothermic by around $50 \mathrm{kcal} \cdot \mathrm{mol}^{-1}$ on both spin state surfaces.

\subsection{Phthalate O-Dealkylation}

Subsequently, we considered the reaction mechanism for O-dealkylation of our phthalate substrate and the obtained potential energy landscape is given in Figure 6. Similar to the aliphatic hydroxylation reaction described in the previous section, the reaction is stepwise with an initial hydrogen atom abstraction via a radical intermediate leading to alcohol products in a highly exothermic process. However, the alcohol is not the final product and with a proton transfer step via transition state $\mathrm{TS}_{\text {dealk }}$ the alkyl group comes off as an aldehyde. Also for O-dealkylation, the hydrogen atom abstraction barrier is the rate-determining barrier in the reaction process with values energy plus zero-point energy of $\Delta E+\mathrm{ZPE}=19.3(20.3) \mathrm{kcal} \cdot \mathrm{mol}^{-1}$ on the quartet (doublet) spin states. The imaginary frequency 
for the hydrogen atom abstraction barriers are large (i1775 and i1726 for ${ }^{4} \mathrm{TS}_{\mathrm{B}}$ and ${ }^{2} \mathrm{TS}_{\mathrm{B}}$, respectively), which is similar to those reported above for ${ }^{4,2} \mathrm{TS}_{\mathrm{A}}$.



Figure 6. Potential energy landscape (B3LYP/BS1 optimized) of phthalate O-dealkylation by P450 CpdI. Relative energies contain zero-point corrections and are taken from B3LYP/BS2//B3LYP/BS1 in $\mathrm{kcal} \cdot \mathrm{mol}^{-1}$. Optimized geometries give bond lengths in angstroms, the $\mathrm{Fe}-\mathrm{O}-\mathrm{C}$ angle in degrees and the imaginary frequency in the transition state in $\mathrm{cm}^{-1}$.

The hydrogen atom abstraction transition state geometries $\left({ }^{4,2} \mathrm{TS}_{\mathrm{B}}\right)$ are similar in structure to ${ }^{4,2} \mathrm{TS}_{\mathrm{A}}$, with long $\mathrm{C}-\mathrm{H}$ and short $\mathrm{O}-\mathrm{H}$ distances; $\mathrm{C}-\mathrm{H}$ bonds of 1.386 and $1.378 \AA$ and $\mathrm{O}-\mathrm{H}$ bonds of 1.165 and $1.160 \AA$ are found for ${ }^{4} \mathrm{TS}_{\mathrm{B}}$ and ${ }^{2} \mathrm{TS}_{\mathrm{B}}$, respectively, indicating that the transition states are also late on the potential energy surface. Intermediates (IB1) are radicals with considerable spin density on the substrate $\mathrm{C}^{1}$ atom ( $\rho_{\mathrm{SubH}}$ is 0.97 for both the quartet and doublet spin states). Similar to the aliphatic hydroxylation pathway from the previous section, the radical intermediates, ${ }^{4,2}$ IB1, are above reactants by about $7-8 \mathrm{kcal} \cdot \mathrm{mol}^{-1}$. On both spin state surfaces we failed to obtain a rebound transition state, but geometry scans point to a facile and fast process with a barrier of less than $1 \mathrm{kcal} \cdot \mathrm{mol}^{-1}$, leading to the intermediate, ${ }^{4,2} \mathrm{IB} 2$. The radical disappears upon formation of the alcohol intermediate, ${ }^{4,2} \mathrm{IB} 2$, en route to the O-dealkylation product, ${ }^{4,2} \mathrm{~PB}$. The last step of dealkylation happens away from the P450 active site and can be catalyzed by a solvent water molecule. Thus, when we add a bridging water molecule to the substrate alcohol position a dealkylation barrier of $11.5 \mathrm{kcal} \cdot \mathrm{mol}^{-1}$ is obtained for proton relay, from the alcohol group to the carbonyl of the ester bond. This breaks the ester bond and releases ortho-phthalic acid in a process that is exothermic by $5.8 \mathrm{kcal} \cdot \mathrm{mol}^{-1}$. Subsequent inclusion of water molecules in the model may even bring the barrier further down, as evidenced in previous studies on P450 catalyzed dealkylation [70].

\subsection{Phthalate Epoxidation and Aromatic Hydroxylation}

The final two pathways of phthalate oxidation by P450 CpdI that were considered are substrate epoxidation and aromatic hydroxylation, which both start with an electrophilic attack of the oxo group on one of the carbon atoms of the aromatic ring to form a radical intermediate, ${ }^{2,4} \mathrm{IC}$. From this intermediate, the landscape is seen to bifurcate into two directions (Figure 7). Firstly, a ring-closure transition state $\left(\mathrm{TS}_{\mathrm{rcC}}\right)$ leads to epoxide product complexes (PC). Secondly, from IC the ipso-proton can transfer from the benzene ring to one of the nitrogen atoms of porphyrin to form intermediate ID in a highly exothermic reaction step and without a reaction barrier. A small proton-reshuttle 
barrier $\mathrm{TS}_{\mathrm{PT}}$ of less than $1 \mathrm{kcal} \cdot \mathrm{mol}^{-1}$ transfers the proton to the oxygen atom to form phenol products (PD). An alternative proton transfer pathway from ${ }^{4,2} \mathrm{ID}$ leads, via a significantly higher barrier, to ketone products.



Figure 7. Potential energy landscape (B3LYP/BS1 optimized) of epoxidation and aromatic hydroxylation of phthalate by $\mathrm{P} 450 \mathrm{CpdI}$. Relative energies contain zero-point corrections and are taken from $\mathrm{B} 3 \mathrm{LYP} / \mathrm{BS} 2 / / \mathrm{B} 3 \mathrm{LYP} / \mathrm{BS} 1$ in $\mathrm{kcal} \cdot \mathrm{mol}^{-1}$. Optimized geometries give bond lengths in angstroms, the $\mathrm{Fe}-\mathrm{O}-\mathrm{C}$ angle in degrees and the imaginary frequency in the transition state in $\mathrm{cm}^{-1}$.

The electrophilic attack of the oxo group on the ortho carbon atom, with respect to the carboxylic acid substituents of the aromatic ring, passes transition states ${ }^{4,2} \mathrm{TS}_{\mathrm{C}}$, at a cost of $20.9(22.8) \mathrm{kcal} \cdot \mathrm{mol}^{-1}$ on the doublet (quartet) spin states. These transition states have elongated $\mathrm{Fe}-\mathrm{O}$ bond lengths of 1.717 (1.709) $\AA$ and long O-C bond lengths of $1.793(1.828) \AA$ for ${ }^{4} \mathrm{TS}_{\mathrm{C}}\left({ }^{2} \mathrm{TS}_{\mathrm{C}}\right)$, respectively. The potential energy surface is broad and hence a small imaginary frequency of well below $i 600 \mathrm{~cm}^{-1}$ is found. Geometrically, the structures are upright, with an Fe-O-C angle of $136^{\circ}\left(132^{\circ}\right)$ and match earlier calculated structures of the aromatic hydroxylation mechanism by P450 CpdI using different substrates [36-39,66,71].

After the transition state, the systems relax to radical intermediates $\left({ }^{4,2} \mathrm{IC}\right)$ with spin densities of $\rho_{\mathrm{FeO}}=2.31$ and $\rho_{\mathrm{SubH}}=1.01$ in the quartet spin state. Both spin states remain degenerate along the pathway, from reactants to IC, as seen above for the other mechanisms as well and are higher in energy than reactants by $13.6(11.8) \mathrm{kcal} \cdot \mathrm{mol}^{-1}$ for ${ }^{4} \mathrm{IC}\left({ }^{2} \mathrm{IC}\right)$. Similar to aliphatic rebound, the ring-closure barriers leading to epoxide products are much higher in energy in the quartet spin state than in the doublet spin state (cf. 7.7 versus $2.5 \mathrm{kcal} \cdot \mathrm{mol}^{-1}$ ). This is a result of promotion of an electron from the substrate into the $\pi_{x z}^{*}$ orbital in the doublet spin state, whereas in the quartet spin state the electron moves to the higher energy $\sigma_{z}^{*}{ }^{2}$ instead. Overall, epoxidation is a thermoneutral process and at our level of theory, it is slightly endothermic in the quartet spin state (by $4.3 \mathrm{kcal} \cdot \mathrm{mol}^{-1}$ ), while it is slightly exothermic in the doublet spin state (by $3.9 \mathrm{kcal} \cdot \mathrm{mol}^{-1}$ ). Structures along the epoxidation pathway are similar to those calculated before on alternative substrates [29-32,72-75]. 
Proton shuttle from the ipso-carbon atom to the porphyrin ring is virtually barrierless and leads, in highly exothermic process, to intermediate ${ }^{4,2} \mathrm{ID}$ and is followed by another small proton transfer barrier ( $\mathrm{TS}_{\mathrm{PT}}$ ) that gives ortho-phenol products (PD). As the barrier height for the conversion of the radical intermediates $\left({ }^{4,2} \mathrm{IC}\right)$ into proton-transfer intermediates $\left({ }^{4,2} \mathrm{ID}\right)$ is significantly smaller than the barrier for ring-closure, it can be concluded that substrate epoxidation is an unlikely process and will not be able to compete with aromatic hydroxylation under these conditions. However, it may come into play in a constraint substrate situation, such as an enzyme active site, where the substrate orientation stabilizes this process.

\section{Discussion}

To understand the regioselectivity patterns of phthalate activation by P450 CpdI, we calculated the mechanisms leading to aliphatic hydroxylation at the $\mathrm{C}^{5}$ position of the aliphatic chain, O-dealkylation, aromatic hydroxylation of the ortho-carbon atom and epoxidation of the aromatic ring. In the next few sections, we will discuss the patterns and the consequences of phthalate activation by the P450s.

\subsection{Regioselectivity of Phthalate Oxidation by P450 CpdI}

Table 1 gives a summary of the rate-determining barriers for hydrogen atom abstraction from the $\mathrm{C}^{5}$ position $\left({ }^{4,2} \mathrm{TS}_{\mathrm{A}}\right)$, hydrogen atom abstraction from the $\mathrm{C}^{1}$ position $\left({ }^{4,2} \mathrm{TS}_{\mathrm{B}}\right)$ and electrophilic addition to the ortho-position at the aromatic ring $\left({ }^{4,2} \mathrm{TS}_{\mathrm{C}}\right)$. It can be seen that all barriers at the $\Delta E+\mathrm{ZPE}$ level of theory fall inside a window of $4.6 \mathrm{kcal} \cdot \mathrm{mol}^{-1}$, with the lowest one through ${ }^{2} \mathrm{TS}_{\mathrm{A}}$ at $18.2 \mathrm{kcal} \cdot \mathrm{mol}^{-1}$. This implies that the dominant reaction pathway ideally should lead to $\mathrm{C}^{5}$ activation in the doublet spin state, but the other barriers for $\mathrm{C}^{5}$ and $\mathrm{C}^{1}$ activation are within $2 \mathrm{kcal} \cdot \mathrm{mol}^{-1}$ and hence will be competitive. The same trends and transition state ordering is found at the free energy level of theory. The only difference between $\Delta E+Z \mathrm{PE}$ and $\Delta G$ is a raise in the value of the latter, due to the addition of entropy. Nevertheless, the entropy effect appears to be similar for all transition states and pathways covered.

Table 1. Calculated rate determining barrier heights for various oxidation reactions.

\begin{tabular}{ccc}
\hline Barrier & Doublet $^{\mathbf{1}^{1}}$ & Quartet $^{\mathbf{1}^{1}}$ \\
\hline${ }^{4,2} \mathrm{TS}_{\mathrm{A}}$ & $18.2(32.4)$ & $19.9(33.6)$ \\
${ }^{4,2} \mathrm{TS}_{\mathrm{B}}$ & $20.3(34.2)$ & $19.3(32.6)$ \\
${ }^{4,2} \mathrm{TS}_{\mathrm{C}}$ & $20.9(34.8)$ & $22.8(36.8)$ \\
\hline \multicolumn{2}{c}{$\Delta E+$ ZPE $(\Delta G)$ values in $\mathrm{kcal} \cdot \mathrm{mol}^{-1}}$.
\end{tabular}

Although the energy differences between aliphatic hydrogen atom abstraction at the $\mathrm{C}^{5}$ and $C^{1}$ positions are very small and also close in energy to the electrophilic addition transition state in our model system, this does not necessarily mean that $C^{5}$ hydroxylation is the dominant process in the enzyme. Experimental studies on phthalate activation by a range of P450 isozymes showed that the product distributions were strongly dependent on the isozyme [49]. Since each P450 isozyme has a characteristic substrate binding pocket [76], the substrate orientation inside P450 isozymes may be different and consequently the activation of the substrate will give other products. Accordingly, the work of Choi et al. [49] showed that in $\mathrm{P}_{450_{3} \mathrm{~A} 1}$ and $\mathrm{P}_{450_{2} \mathrm{C} 12}$, the dominant product is $\mathrm{C}^{5}$ hydroxylation, whereas in $\mathrm{P}_{45} 0_{2 \mathrm{D} 6}$ mostly O-dealkylation was found. However, in $\mathrm{P} 450_{3 \mathrm{~A} 4}, \mathrm{P}_{450_{2} \mathrm{C} 6}$ and $\mathrm{P}_{450_{3} \mathrm{~A} 5}$, a mixture of products, originating from O-dealkylation and $\mathrm{C}^{5}$-hydroxylation, was found. Our computational modelling gives a small energy difference in the rate-determining barrier heights of $\mathrm{C}^{5}$ hydrogen atom abstraction versus $\mathrm{C}^{1}$ hydrogen atom abstraction (for O-dealkylation), with a small preference of about $1 \mathrm{kcal} \cdot \mathrm{mol}^{-1}$ in favor of $\mathrm{C}^{5}$ activation. Consequently, under ideal conditions, the dominant product should be $\mathrm{C}^{5}$ hydroxylation, but, if that pathway is hindered, due to substrate positioning, alternative mechanisms may become available. To understand the preferences better, we 
took a P450 structure of a liver P450 isozyme from the protein databank [77],-i.e., the 1TQN pdb file [78], which is a $\mathrm{P}^{4} 50_{3 \mathrm{~A} 4}$ isozyme. The substrate was docked into the substrate-binding pocket, using SwissDock [79], and thereafter the active site was modified to a CpdI model by addition of an oxo group. Some plausible conformations of the substrate orientation in the $\mathrm{P}^{4} \mathrm{~S}_{3 \mathrm{~A} 4}$ pocket are shown in Figure 8.

(a)



(b)

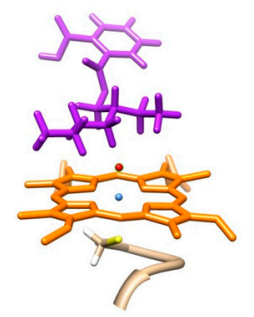

Figure 8. Two plausible conformations of the cytochrome $\mathrm{P}^{4} 50_{3 \mathrm{~A} 4}$ structure with phthalate substrate $(\mathrm{SubH})$ docked into the substrate binding pocket: (a) pro- $\mathrm{C}^{5}$-hydroxylation binding; (b) pro-O-dealkylation binding.

We found two low-energy conformations as shown in Figure 8; one with the substrate in a pro- $\mathrm{C}^{5}$-hydroxylation conformation and one with the substrate in a pro-O-dealkylation conformation. In the pro- $\mathrm{C}^{5}$-hydroxylation binding conformation, the docked structure (Figure 8a) is in a conformation with the aliphatic chains in close approach to the iron(IV)-oxo group, in a crown-shaped orientation with the protons of the $\mathrm{C}^{5}$ and $\mathrm{C}^{3}$ positions of the hexyl group as well as the terminal hydrogen atom from the ethyl group $\left(\mathrm{C}^{8}\right)$ pointing towards the oxo group. In particular, distances found were: $2.10 \AA$ for $\mathrm{C}^{5} \mathrm{H}-\mathrm{O}, 2.06 \AA$ for $\mathrm{C}^{3} \mathrm{H}-\mathrm{O}$ and $3.07 \AA$ for $\mathrm{C}^{8} \mathrm{H}-\mathrm{O}$. Clearly, the aliphatic group fits into the cavity nearby the iron(IV)-oxo species well and should lead to aliphatic hydroxylation products. This means that the most likely substrate activation positions in this binding configuration will be on the terminus of the aliphatic chain, i.e., the $\mathrm{C}^{5}$ position for which we calculated a low-energy barrier height. On the other hand, the aromatic ring is positioned far away from CpdI and as such we do not expect significant aromatic hydroxylation products.

In the alternative conformation in Figure 8b, we positioned the $C^{1}$ carbon in close distance to the oxo group, while the aromatic ring and the alkyl chains were pointing away from the heme group. In this orientation, the ester bond is in hydrogen bonding interaction with the positive side chain of $\operatorname{Arg}_{212}$, which may facilitate the O-dealkylation process through charge stabilization. Moreover, in this binding position, O-dealkylation will be the dominant process and no aliphatic hydroxylation on the side chains will take place.

Consequently, substrate activation by the P450s is a subtle balance of thermochemical and kinetical possibilities with substrate binding and orientation that go hand-in-hand. To understand the thermochemistry better, in the next section we discuss aliphatic $\mathrm{C}-\mathrm{H}$ bond activation in more detail.

\subsection{Features of the Hydrogen Atom Abstraction Step}

To understand the intrinsic properties related to the hydrogen atom abstraction step, we devised valence bond models to explain the features of the reaction pathway following procedures described previously [80-82]. Figure 9 displays a valence bond (VB) description of the electronic configurations of reactants, hydrogen atom abstraction transition states and radical intermediates. Thus, in the reactants, CpdI has two 3-electron bonds along the Fe-O interaction, due to occupation of the $\pi_{x z}{ }^{2} \pi_{y z}{ }^{2} \pi_{x z}^{*}{ }^{1}$ $\pi^{*} y z$ with six electrons, which gives two unpaired electrons at the FeO group and a spin density of about 1 on $\mathrm{Fe}$ and $\mathrm{O}$. CpdI has a third unpaired electron in $\mathrm{a}_{2 \mathrm{u}}$ and the $\mathrm{C}-\mathrm{H}$ bond of the substrate is the $\sigma_{\mathrm{CH}}$ bond with two electrons. Upon approach of $\mathrm{CpdI}$ on the substrate, the $\mathrm{C}-\mathrm{H}$ bond orbital is broken, and the two electrons revert to atomic orbitals, i.e., $2 \mathrm{p}_{\mathrm{C}}$ and $1 \mathrm{~s}_{\mathrm{H}}$. At the same time, the 3-electron bond in the $x z$-plane breaks back to atomic orbitals, namely $2 \mathrm{p}_{\mathrm{O}}{ }^{2} 3 \mathrm{~d}_{x z}{ }^{1}$. One of the electrons from $2 \mathrm{p}_{\mathrm{O}}$ pairs 
up with the incoming hydrogen atom to form the $\mathrm{O}-\mathrm{H}$ bonding orbital $\sigma_{\mathrm{OH}}$. The second electron from $2 p_{O}$ is then promoted into the $a_{2 u}$ orbital.



Figure 9. Valence bond description of hydrogen atom abstraction from the substrate. Dots represent electrons and a line between two dots is a bond with two electrons.

Therefore, the hydrogen atom abstraction barrier will be related to the strength of the $\sigma_{\mathrm{CH}}$ orbital that needs to be broken, the strength of the $\sigma_{\mathrm{OH}}$ orbital that is formed, the strength of the 3-electron $\pi_{x z} / \pi_{x z}^{*}$-orbitals that need to be broken and the promotion energy from $2 \mathrm{p}_{\mathrm{O}}$ to $\mathrm{a}_{2 \mathrm{u}}$. Indeed, previous studies of ours have shown that the hydrogen atom abstraction barriers for a series of substrates correlates with the bond dissociation energy (BDE) of the $\mathrm{C}-\mathrm{H}$ bond that was broken $[26,63,83,84]$. To gain insight into the relative $\mathrm{C}-\mathrm{H}$ bond strengths of the various aliphatic positions of the phthalate substrate, we calculated the $\mathrm{BDE}_{\mathrm{CH}}$ for all aliphatic positions as the diabatic energy between the substrate and the sum of the substrate minus a hydrogen atom and a hydrogen atom, see Figure 10.



Figure 10. $\mathrm{BDE}_{\mathrm{CH}}$ values (in $\mathrm{kcal} \cdot \mathrm{mol}^{-1}$ ) of aliphatic $\mathrm{C}-\mathrm{H}$ positions of the phthalate substrate.

The data in Figure 10 shows that most $\mathrm{C}-\mathrm{H}$ bonds of secondary carbon atoms have a strength that ranges from $98.7 \mathrm{kcal} \cdot \mathrm{mol}^{-1}$ (for the $\mathrm{C}^{3}$ and $\mathrm{C}^{4}$ positions) to $100.3 \mathrm{kcal} \cdot \mathrm{mol}^{-1}$ (for the $\mathrm{C}^{1}$ position). By contrast, the primary carbon atoms-i.e., the terminal methyl groups-have a $\mathrm{C}-\mathrm{H}$ bond strength of $103.3 \mathrm{kcal} \cdot \mathrm{mol}^{-1}\left(\right.$ at $C^{8}$ ) and $103.6 \mathrm{kcal} \cdot \mathrm{mol}^{-1}\left(\right.$ at $\left.C^{6}\right)$, whereas the tertiary carbon atom $C^{2}$ has a $\mathrm{C}-\mathrm{H}$ bond strength of only $97.6 \mathrm{kcal} \cdot \mathrm{mol}^{-1}$. As the full set of $\mathrm{BDE}_{\mathrm{CH}}$ values spans a range of only $5 \mathrm{kcal} \cdot \mathrm{mol}^{-1}$, it is obvious that a large mixture of products can be expected for aliphatic hydroxylation of the alkyl chains. Moreover, substrate positioning will have a major contribution to the product formation and a low-energy binding conformation may block certain $\mathrm{C}-\mathrm{H}$ bonds from being activated by the enzyme. For instance, the substrate binding position in Figure $9 \mathrm{~b}$ gave only one specific $\mathrm{C}-\mathrm{H}$ bond in close distance to the heme-namely $\mathrm{C}^{1}$ - and consequently will lead to dominant 
O-dealkylation. On the other hand, the structure shown in Figure 9a will lead to a mixture of aliphatic hydroxylation products, probably mostly at $\mathrm{C}^{3}$ and $\mathrm{C}^{5}$.

\section{Materials and Methods}

Active site models were selected in accordance with previous research $[85,86]$ as an iron embedded in protoporphyrin IX without side chains and linked to $\mathrm{SH}^{-}$as a mimic of cysteinate and with oxo in the distal position. The phthalate substrate (2-ethylhexyl-phthalate) was selected in the charged-neutral state and all complexes of CpdI with the substrate were calculated in the lowest lying doublet and quartet spin states.

Calculations were performed in Gaussian-09 [87], using density functional theory methods that have been calibrated and benchmarked against experimental rate constants previously [88-91]. In general, the UB3LYP [92,93] hybrid density functional was used for all calculations. Geometry optimizations, frequencies and reaction coordinate scans were done with a modest LACVP basis set with core potential on iron [94] and 6-31 $\mathrm{G}^{*}$ on the rest of the atoms [95]: basis set BS1. More accurate energies were obtained through a single point calculation of the optimized geometry, using an LACV3P+ basis set with core potential on iron and $6-311+G^{*}$ on the rest of the atoms: basis set BS2, as well as an implicit solvent model mimicking the dielectric constant of water [96].

\section{Conclusions}

A computational study on phthalate binding and activation by cytochrome P450 liver enzymes was presented here. Initial calculations used active site models of P450 Compound I in its reaction with the ester of phthalate and 2-ethylhexanol, and patterns for $C^{5}$ hydroxylation, O-dealkylation, aromatic ring epoxidation and ortho-aromatic ring hydroxylation patterns were reported. Aliphatic hydroxylation and O-dealkylation started with hydrogen atom abstraction followed by rebound to give an alcohol product complex. In O-dealkylation, we found the alcohol product to react with an assisted solvent water molecule by O-dealkylation. Epoxidation and aromatic hydroxylation mechanisms are electrophilic and lead to a radical intermediate where the oxo group forms a single bond with one carbon atom of the aromatic ring. This radical can form the epoxide through ring-closure; however, that pathway incurs a significant barrier height. A lower energy pathway leads through proton shuttle from ipso-proton to heme and back to the phenolate to give phenol products. All pathways were analyzed and rationalized with thermochemical, valence bond and kinetic models.

Acknowledgments: Fabián G. Cantú Reinhard thanks the Conacyt Mexico for a studentship.

Author Contributions: Fabián G. Cantú Reinhard and Sam P. de Visser conceived and designed the experiments and analyzed the data; Fabián G. Cantú Reinhard performed the experiments; Sam P. de Visser wrote the paper.

Conflicts of Interest: The authors declare no conflict of interest.

\section{References}

1. Sono, M.; Roach, M.P.; Coulter, E.D.; Dawson, J.H. Heme-containing oxygenases. Chem. Rev. 1996, 96, 2841-2887. [CrossRef] [PubMed]

2. Ortiz de Montellano, P.R. (Ed.) Cytochrome P450: Structure, Mechanism, and Biochemistry, 3rd ed.; Kluwer Academic/Plenum Publishers: New York, NY, USA, 2004.

3. Meunier, B.; de Visser, S.P.; Shaik, S. Mechanism of oxidation reactions catalyzed by cytochrome P450 enzymes. Chem. Rev. 2004, 104, 3947-3980. [CrossRef] [PubMed]

4. Denisov, I.G.; Makris, T.M.; Sligar, S.G.; Schlichting, I. Structure and chemistry of cytochrome P450. Chem. Rev. 2005, 105, 2253-2277. [CrossRef] [PubMed]

5. Munro, A.W.; Girvan, H.M.; McLean, K.J. Variations on a (t)heme-Novel mechanisms, redox partners and catalytic functions in the cytochrome P450 superfamily. Nat. Prod. Rep. 2007, 24, 585-609. [CrossRef] [PubMed] 
6. Ortiz de Montellano, P.R. Hydrocarbon hydroxylation by cytochrome P450 enzymes. Chem. Rev. 2010, 110, 932-948. [CrossRef] [PubMed]

7. Xu, J.; Wang, X.; Guo, W. The cytochrome P450 superfamily: Key players in plant development and defense. J. Integr. Agricult. 2015, 14, 1673-1686. [CrossRef]

8. Fujikura, K.; Ingelman-Sundberg, M.; Lauschke, V. Genetic variation in the human cytochrome P450 supergene family. Pharmacogenetics Genom. 2015, 12, 584-594. [CrossRef] [PubMed]

9. Groves, J.T. The bioinorganic chemistry of iron in oxygenases and supramolecular assemblies. Proc. Natl. Acad. Sci. USA 2003, 100, 3569-3574. [CrossRef] [PubMed]

10. Watanabe, Y.; Nakajima, H.; Ueno, T. Reactivities of oxo and peroxo intermediates studied by hemoprotein mutants. Acc. Chem. Res. 2007, 40, 554-562. [CrossRef] [PubMed]

11. De Visser, S.P.; Nam, W. High-valent iron-oxo porphyrins in oxygenation reactions. In Handbook of Porphyrin Science; Kadish, K.M., Smith, K.M., Guilard, R., Eds.; World Scientific Publishing Co.: Hackensack, NJ, USA, 2010; pp. 85-140, ISBN-13 978-981-4307-23-9.

12. Belcher, J.; McLean, K.J.; Matthews, S.; Woodward, L.S.; Fischer, K.; Rigby, S.E.J.; Nelson, D.R.; Potts, D.; Baynham, M.T.; Parker, D.A.; et al. Structure and biochemical properties of the alkene producing cytochrome P450 OleTJE (CYP152L1) from the Jeotgalicoccus sp. 8456 bacterium. J. Biol. Chem. 2014, 289, 6535-6550. [CrossRef] [PubMed]

13. Kumar, D.; Hirao, H.; de Visser, S.P.; Zheng, J.; Wang, D.; Thiel, W.; Shaik, S. New features in the catalytic cycle of cytochrome P450 during the formation of Compound I from Compound 0. J. Phys. Chem. B 2005, 109, 19946-19951. [CrossRef] [PubMed]

14. Shaik, S.; Kumar, D.; de Visser, S.P.; Altun, A.; Thiel, W. Theoretical perspective on the structure and mechanism of cytochrome P450 enzymes. Chem. Rev. 2005, 105, 2279-2328. [CrossRef] [PubMed]

15. Rittle, J.; Green, M.T. Cytochrome P450 Compound I: Capture, characterization, and C-H bond activation kinetics. Science 2010, 330, 933-937. [CrossRef] [PubMed]

16. Davydov, R.; Perera, R.; Jin, S.; Yang, T.-C.; Bryson, T.A.; Sono, M.; Dawson, J.H.; Hoffman, B.M. Substrate modulation of the properties and reactivity of the oxy-ferrous and hydroperoxo-ferric intermediates of cytochrome P450 cam as shown by cryoreduction-EPR/ENDOR spectroscopy. J. Am. Chem. Soc. 2005, 127, 1403-1414. [CrossRef] [PubMed]

17. Song, W.J.; Ryu, Y.O.; Song, R.; Nam, W. Oxoiron(IV) porphyrin $\pi$-cation radical complexes with a chameleon behavior in cytochrome P450 model reactions. J. Biol. Inorg. Chem. 2005, 10, 294-304. [CrossRef] [PubMed]

18. Ogliaro, F.; de Visser, S.P.; Cohen, S.; Sharma, P.K.; Shaik, S. Searching for the second oxidant in the catalytic cycle of cytochrome P450: A theoretical investigation of the iron(III)-hydroperoxo species and its epoxidation pathways. J. Am. Chem. Soc. 2002, 124, 2806-2817. [CrossRef] [PubMed]

19. Sharma, P.K.; Kevorkiants, R.; de Visser, S.P.; Kumar, D.; Shaik, S. Porphyrin trap its own terminator! Concerted and stepwise porphyrin degradation mechanisms induced by heme-oxygenase vs. cytochrome P450. Angew. Chem. Int. Ed. 2004, 43, 1129-1132. [CrossRef] [PubMed]

20. Thibon, A.; Jollet, V.; Ribal, C.; Sénéchal-David, K.; Billon, L.; Sorokin, A.B.; Banse, F. Hydroxylation of aromatics with the help of a non-haem FeOOH: A mechanistic study under single-turnover and catalytic conditions. Chem. Eur. J. 2012, 18, 2715-2724. [CrossRef] [PubMed]

21. Vardhaman, A.K.; Barman, P.; Kumar, S.; Sastri, C.V.; Kumar, D.; de Visser, S.P. Mechanistic insight into halide oxidation by non-heme iron complexes. Haloperoxidase versus halogenase activity. Chem. Commun. 2013, 49, 10926-10928. [CrossRef] [PubMed]

22. Faponle, A.S.; Quesne, M.G.; Sastri, C.V.; Banse, F.; de Visser, S.P. Differences and comparisons of the properties and reactivities of iron(III)-hydroperoxo complexes with saturated coordination sphere. Chem. Eur. J. 2015, 21, 1221-1236. [CrossRef] [PubMed]

23. Blomberg, M.R.A.; Borowski, T.; Himo, F.; Liao, R.Z.; Siegbahn, P.E.M. Quantum chemical studies of mechanisms for metalloenzymes. Chem. Rev. 2014, 114, 3601-3658. [CrossRef] [PubMed]

24. Ogliaro, F.; Harris, N.; Cohen, S.; Filatov, M.; de Visser, S.P.; Shaik, S. A Model “Rebound” Mechanism of Hydroxylation by Cytochrome P450: Stepwise and effectively concerted pathways, and their reactivity patterns. J. Am. Chem. Soc. 2000, 122, 8977-8989. [CrossRef]

25. Kamachi, T.; Yoshizawa, K. A theoretical study on the mechanism of camphor hydroxylation by compound I of cytochrome P450. J. Am. Chem. Soc. 2003, 125, 4652-4661. [CrossRef] [PubMed] 
26. De Visser, S.P.; Kumar, D.; Cohen, S.; Shacham, R.; Shaik, S. A predictive pattern of computed barriers for C-H hydroxylation by Compound I of cytochrome P450. J. Am. Chem. Soc. 2004, 126, 8362-8363. [CrossRef] [PubMed]

27. Li, X.-X.; Postils, V.; Sun, W.; Faponle, A.S.; Solà, M.; Wang, Y.; Nam, W.; de Visser, S.P. Reactivity patterns of (protonated) Compound II and Compound I of Cytochrome P450: Which is the better oxidant? Chem. Eur. J. 2017, 23, 6406-6418. [CrossRef] [PubMed]

28. Shaik, S.; Cohen, S.; de Visser, S.P.; Sharma, P.K.; Kumar, D.; Kozuch, S.; Ogliaro, F.; Danovich, D. The "rebound controversy": An overview and theoretical modeling of the rebound step in C-H hydroxylation by cytochrome P450. Eur. J. Inorg. Chem. 2004, 207-226. [CrossRef]

29. De Visser, S.P.; Ogliaro, F.; Harris, N.; Shaik, S. Multi-state epoxidation of ethene by cytochrome P450: A quantum chemical study. J. Am. Chem. Soc. 2001, 123, 3037-3047. [CrossRef] [PubMed]

30. De Visser, S.P.; Ogliaro, F.; Sharma, P.K.; Shaik, S. Hydrogen bonding modulates the selectivity of enzymatic oxidation by P450: A chameleon oxidant behavior of Compound I. Angew. Chem. Int. Ed. 2002, 41, 1947-1951. [CrossRef]

31. Kumar, D.; Karamzadeh, B.; Sastry, G.N.; de Visser, S.P. What factors influence the rate constant of substrate epoxidation by Compound I of cytochrome P450 and analogous iron(IV)-oxo oxidants. J. Am. Chem. Soc. 2010, 132, 7656-7667. [CrossRef] [PubMed]

32. Sainna, M.A.; Kumar, S.; Kumar, D.; Fornarini, S.; Crestoni, M.E.; de Visser, S.P. A comprehensive test set of epoxidation rate constants by iron(IV)-oxo porphyrin complexes. Chem. Sci. 2015, 6, 1516-1529. [CrossRef]

33. Sharma, P.K.; de Visser, S.P.; Shaik, S. Can a single oxidant with two spin states masquerade as two different oxidants? A study of the sulfoxidation mechanism by cytochrome P450. J. Am. Chem. Soc. 2003, 125, 8698-8699. [CrossRef] [PubMed]

34. Kumar, D.; de Visser, S.P.; Sharma, P.K.; Hirao, H.; Shaik, S. Sulfoxidation mechanisms catalyzed by cytochrome P450 and horseradish peroxidase models: Spin selection induced by the ligand. Biochemistry 2005, 44, 8148-8158. [CrossRef] [PubMed]

35. Kumar, D.; Sastry, G.N.; de Visser, S.P. Effect of the axial ligand on substrate sulfoxidation mediated by iron(IV)-oxo porphyrin cation radical oxidants. Chem. Eur. J. 2011, 17, 6196-6205. [CrossRef] [PubMed]

36. De Visser, S.P.; Shaik, S. A proton-shuttle mechanism mediated by the porphyrin in benzene hydroxylation by cytochrome P450 enzymes. J. Am. Chem. Soc. 2003, 125, 7413-7424. [CrossRef] [PubMed]

37. De Visser, S.P.; Oh, K.; Han, A.-R.; Nam, W. Combined experimental and theoretical study on aromatic hydroxylation by mononuclear nonheme iron(IV)-oxo complexes. Inorg. Chem. 2007, 46, 4632-4641. [CrossRef] [PubMed]

38. Kumar, D.; Sastry, G.N.; de Visser, S.P. Axial ligand effect on the rate constant of aromatic hydroxylation by iron(IV)-oxo complexes mimicking cytochrome P450 enzymes. J. Phys. Chem. B 2012, 116, 718-730. [CrossRef] [PubMed]

39. Cantú Reinhard, F.G.; Sainna, M.A.; Upadhyay, P.; Balan, G.A.; Kumar, D.; Fornarini, S.; Crestoni, M.E.; de Visser, S.P. A systematic account on aromatic hydroxylation by a cytochrome P450 model Compound I: A low-pressure mass spectrometry and computational study. Chem. Eur. J. 2016, 22, 18608-18619. [CrossRef] [PubMed]

40. Tang, M.-C.; Zou, Y.; Watanabe, K.; Walsh, C.T.; Tang, Y. Oxidative cyclization in natural product biosynthesis. Chem. Rev. 2017, 107, 5226-5333. [CrossRef] [PubMed]

41. Rettie, A.E.; Rettenmeier, A.W.; Howald, W.N.; Baillie, T.A. Cytochrome P-450-catalyzed formation of delta4-VPA, a toxic metabolite of valproic acid. Science 1987, 235, 890-893. [CrossRef] [PubMed]

42. Lee, R.P.; Parkinson, A.; Forkert, P.-G. Isozyme-selective metabolism of ethyl carbamate by cytochrome P450 (CYP2E1) and carboxylesterase (hydrolase A) enzymes in murine liver microsomes. Drug Metabol. Disp. 1998, 26, 60-65.

43. Guengerich, F.P.; Kim, D.H. Enzymic oxidation of ethyl carbamate to vinyl carbamate and its role as an intermediate in the formation of 1,N6-ethenoadenosine. Chem. Res. Toxicol. 1991, 4, 413-421. [CrossRef] [PubMed]

44. Kumar, D.; de Visser, S.P.; Shaik, S. Oxygen economy of cytochrome P450: What is the origin of the mixed functionality as a dehydrogenase-oxidase enzyme compared with its normal function? J. Am. Chem. Soc. 2004, 126, 5072-5073. [CrossRef] [PubMed] 
45. Ji, L.; Faponle, A.S.; Quesne, M.G.; Sainna, M.A.; Zhang, J.; Franke, A.; Kumar, D.; van Eldik, R.; Liu, W.; de Visser, S.P. Drug metabolism by cytochrome P450 enzymes: What distinguishes the pathways leading to substrate hydroxylation over desaturation? Chem. Eur. J. 2015, 21, 9083-9092. [CrossRef] [PubMed]

46. Rude, M.A.; Baron, T.S.; Brubaker, S.; Alibhai, M.; Del Cardayre, S.B.; Schirmer, A. Terminal olefin (1-alkene) biosynthesis by a novel P450 fatty acid decarboxylase from Jeotgalicoccus species. Appl. Environm. Microbiol. 2011, 77, 1718-1727. [CrossRef] [PubMed]

47. Grant, J.L.; Hsieh, C.H.; Makris, T.M. Decarboxylation of fatty acids to terminal alkenes by cytochrome P450 compound I. J. Am. Chem. Soc. 2015, 137, 4940-4943. [CrossRef] [PubMed]

48. Faponle, A.S.; Quesne, M.G.; de Visser, S.P. Origin of the regioselective fatty acid hydroxylation versus decarboxylation by a cytochrome $\mathrm{P} 450$ peroxygenase: What drives the reaction to biofuel production? Chem. Eur. J. 2016, 22, 5478-5483. [CrossRef] [PubMed]

49. Choi, K.; Joo, H.; Campbell, J.L., Jr.; Clewell, R.A.; Andersen, M.E.; Clewell, H.J., III. In vitro metabolism of di(2-ethylhexyl) phthalate (DEHP) by various tissues and cytochrome P450s of human and rat. Toxicol. In Vitro 2012, 26, 315-322. [CrossRef] [PubMed]

50. Ogliaro, F.; de Visser, S.P.; Cohen, S.; Kaneti, J.; Shaik, S. The experimentally elusive oxidant of cytochrome P450: A theoretical "trapping" defining more closely the "real" species. ChemBioChem 2001, 2, 848-851. [CrossRef]

51. De Visser, S.P.; Shaik, S.; Sharma, P.K.; Kumar, D.; Thiel, W. Active species of horseradish peroxidase (HRP) and cytochrome P450: Two electronic chameleons. J. Am. Chem. Soc. 2003, 125, 15779-15788. [CrossRef] [PubMed]

52. Cantú Reinhard, F.G.; de Visser, S.P. Oxygen atom transfer using an iron(IV)-oxo embedded in a tetracyclic $\mathrm{N}$-heterocyclic carbene system: How does the reactivity compare to Cytochrome P450 Compound I? Chem. Eur. J. 2017, 23, 2935-2944. [CrossRef] [PubMed]

53. Kumar, D.; de Visser, S.P.; Shaik, S. How does product isotope effect prove the operation of a two-state "rebound" mechanism in C-H hydroxylation by cytochrome P450? J. Am. Chem. Soc. 2003, 125, 13024-13025. [CrossRef] [PubMed]

54. Kumar, D.; de Visser, S.P.; Sharma, P.K.; Cohen, S.; Shaik, S. Radical clock substrates, their C-H hydroxylation mechanism by cytochrome $\mathrm{P} 450$ and other reactivity patterns: What does theory reveal about the clocks' behavior? J. Am. Chem. Soc. 2004, 126, 1907-1920. [CrossRef] [PubMed]

55. De Visser, S.P. Differences in and comparison of the catalytic properties of heme and non-heme enzymes with a central oxo-iron group. Angew. Chem. Int. Ed. 2006, 45, 1790-1793. [CrossRef] [PubMed]

56. De Visser, S.P.; Tan, L.S. Is the bound substrate in nitric oxide synthase protonated or neutral and what is the active oxidant that performs substrate hydroxylation? J. Am. Chem. Soc. 2008, 130, 12961-12974. [CrossRef] [PubMed]

57. Green, M.T. Evidence for sulfur-based radicals in thiolate Compound I intermediates. J. Am. Chem. Soc. 1999, 121, 7939-7940. [CrossRef]

58. Schöneboom, J.C.; Lin, H.; Reuter, N.; Thiel, W.; Cohen, S.; Ogliaro, F.; Shaik, S. The elusive oxidant species of cytochrome P450 enzymes: Characterization by combined quantum mechanical/molecular mechanical (QM/MM) calculations. J. Am. Chem. Soc. 2002, 124, 8142-8151. [CrossRef] [PubMed]

59. Bathelt, C.M.; Mulholland, A.J.; Harvey, J.N. QM/MM modeling of benzene hydroxylation in human cytochrome P450 2C9. J. Phys. Chem. A 2008, 112, 13149-13156. [CrossRef] [PubMed]

60. Porro, C.S.; Sutcliffe, M.J.; de Visser, S.P. Quantum mechanics/molecular mechanics studies on the sulfoxidation of dimethyl sulfide by Compound I and Compound 0 of Cytochrome P450: Which is the better oxidant? J. Phys. Chem. A 2009, 113, 11635-11642. [CrossRef] [PubMed]

61. Ogliaro, F.; Cohen, S.; de Visser, S.P.; Shaik, S. Medium polarization and hydrogen bonding effects on Compound I of cytochrome P450: what kind of a radical is it really? J. Am. Chem. Soc. 2000, 122, 12892-12893. [CrossRef]

62. De Visser, S.P. What external perturbations influence the electronic properties of catalase Compound I? Inorg. Chem. 2006, 45, 9551-9557. [CrossRef] [PubMed]

63. De Visser, S.P. Trends in substrate hydroxylation reactions by heme and nonheme iron(IV)-oxo oxidants give correlations between intrinsic properties of the oxidant with barrier height. J. Am. Chem. Soc. 2010, 132, 1087-1097. [CrossRef] [PubMed] 
64. Barman, P.; Upadhyay, P.; Faponle, A.S.; Kumar, J.; Nag, S.S.; Kumar, D.; Sastri, C.V.; de Visser, S.P. Deformylation reaction by a nonheme manganese(III)-peroxo complex via initial hydrogen atom abstraction. Angew. Chem. Int. Ed. 2016, 55, 11091-11095. [CrossRef] [PubMed]

65. Timmins, A.; Saint-André, M.; de Visser, S.P. Understanding how prolyl-4-hydroxylase structure steers a ferryl oxidant toward scission of a strong C-H bond. J. Am. Chem. Soc. 2017, 139, 9855-9866. [CrossRef] [PubMed]

66. De Visser, S.P. Substitution of hydrogen by deuterium changes the regioselectivity of ethylbenzene hydroxylation by an oxo-iron-porphyrin catalyst. Chem. Eur. J. 2006, 12, 8168-8177. [CrossRef] [PubMed]

67. Shaik, S.; de Visser, S.P.; Ogliaro, F.; Schwarz, H.; Detlef Schröder, D. Two-state reactivity (TSR) mechanisms of hydroxylation and epoxidation by cytochrome P450 revealed by theory. Curr. Opin. Chem. Biol. 2002, 6, 556-567. [CrossRef]

68. Sharma, P.K.; de Visser, S.P.; Ogliaro, F.; Shaik, S. Is the ruthenium analogue of Compound I of cytochrome P450 an efficient oxidant? A theoretical investigation of the methane hydroxylation reaction. J. Am. Chem. Soc. 2003, 125, 2291-2300. [CrossRef] [PubMed]

69. Singh, D.; Kumar, D.; de Visser, S.P. Methane hydroxylation by axially ligated iron(IV)-oxo porphyrin cation radical models. Int. J. Sc. Technol. 2015, 1, 26-40. [CrossRef]

70. Schyman, P.; Usharani, D.; Wang, Y.; Shaik, S. Brain Chemistry: How does P450 catalyze the O-demethylation reaction of 5-methoxytryptamine to yield serotonin? J. Phys. Chem. B. 2010, 114, 7078-7089. [CrossRef] [PubMed]

71. De Visser, S.P.; Tahsini, L.; Nam, W. How does the axial ligand of cytochrome P450 biomimetics influence the regioselectivity of aliphatic versus aromatic hydroxylation? Chem. Eur. J. 2009, 15, 5577-5587. [CrossRef] [PubMed]

72. Kumar, D.; de Visser, S.P.; Shaik, S. Multistate reactivity in styrene epoxidation by Compound I of cytochrome P450: Mechanisms of products and side products formation. Chem. Eur. J. 2005, 11, 2825-2835. [CrossRef] [PubMed]

73. Kumar, D.; Latifi, R.; Kumar, S.; Rybak-Akimova, E.V.; Sainna, M.A.; de Visser, S.P. Rationalization of the barrier height for para-Z-styrene epoxidation by iron(IV)-oxo porphyrins with variable axial ligands. Inorg. Chem. 2013, 52, 7968-7979. [CrossRef] [PubMed]

74. De Visser, S.P.; Ogliaro, F.; Shaik, S. How does ethene inactivate cytochrome P450 en route to its epoxidation? A density functional study. Angew. Chem. Int. Ed. 2001, 40, 2871-2874. [CrossRef]

75. De Visser, S.P.; Ogliaro, F.; Sharma, P.K.; Shaik, S. What factors affect the regioselectivity of oxidation by cytochrome P450? A DFT study of allylic hydroxylation and double bond epoxidation in a model reaction. J. Am. Chem. Soc. 2002, 124, 11809-11826. [CrossRef] [PubMed]

76. Poulos, T.L. Heme enzyme structure and function. Chem. Rev. 2014, 114, 3919-3962. [CrossRef] [PubMed]

77. Berman, H.M.; Westbrook, J.; Feng, Z.; Gilliland, G.; Bhat, T.N.; Weissig, H.; Shindyalov, I.N.; Bourne, P.E. The Protein Data Bank. Nucleic Acids Res. 2000, 28, 235-242. [CrossRef] [PubMed]

78. Yano, J.K.; Wester, M.R.; Schoch, G.A.; Griffin, K.J.; Stout, C.D.; Johnson, E.F. The structure of human microsomal cytochrome P450 3A4 determined by X-ray crystallography to $2.05 \AA$ A resolution. J. Biol. Chem. 2004, 279, 38091-38094. [CrossRef] [PubMed]

79. Grosdidier, A.; Zoete, V.; Michielin, O. SwissDock, a protein-small molecule docking web service based on EADock DSS. Nucleic Acids Res. 2011, 39. [CrossRef] [PubMed]

80. De Visser, S.P. Propene activation by the oxo-iron active species of taurine $/ \alpha$-ketoglutarate dioxygenase (TauD) enzyme. How does the catalysis compare to heme-enzymes? J. Am. Chem. Soc. 2006, 128, 9813-9824. [CrossRef] [PubMed]

81. Kumar, S.; Faponle, A.S.; Barman, P.; Vardhaman, A.K.; Sastri, C.V.; Kumar, D.; de Visser, S.P. Long-range electron transfer triggers mechanistic differences between iron(IV)-oxo and iron(IV)-imido oxidants. J. Am. Chem. Soc. 2014, 136, 17102-17115. [CrossRef] [PubMed]

82. Quesne, M.G.; Senthilnathan, D.; Singh, D.; Kumar, D.; Maldivi, P.; Sorokin, A.B.; de Visser, S.P. Origin of the enhanced reactivity of $\mu$-nitrido-bridged diiron(IV)-oxo porphyrinoid complexes over cytochrome P450 Compound I. ACS Catal. 2016, 6, 2230-2243. [CrossRef]

83. Shaik, S.; Kumar, D.; de Visser, S.P. A valence bond modeling of trends in hydrogen abstraction barriers and transition states of hydroxylation reactions catalyzed by cytochrome P450 enzymes. J. Am. Chem. Soc. 2008, 130, 10128-10140. [CrossRef] [PubMed] 
84. Karamzadeh, B.; Kumar, D.; Sastry, G.N.; de Visser, S.P. Steric factors override thermodynamic driving force in regioselectivity of proline hydroxylation by prolyl-4-hydroxylase enzymes. J. Phys. Chem. A 2010, 114, 13234-13243. [CrossRef] [PubMed]

85. Ogliaro, F.; de Visser, S.P.; Groves, J.T.; Sason Shaik, S. Chameleon states: High-valent metal-oxo species of cytochrome P450 and its ruthenium analog. Angew. Chem. Int. Ed. 2001, 40, 2874-2878. [CrossRef]

86. De Visser, S.P.; Kumar, D.; Neumann, R.; Shaik, S. Computer-generated high-valent iron-oxo and manganese-oxo species with polyoxometalate ligands: How do they compare with the iron-oxo active species of heme enzymes? Angew. Chem. Int. Ed. 2004, 43, 5661-5665. [CrossRef] [PubMed]

87. Frisch, M.J.; Trucks, G.W.; Schlegel, H.B.; Scuseria, G.E.; Robb, M.A.; Cheeseman, J.R.; Scalmani, G.; Barone, V.; Petersson, G.A.; Nakatsuji, H.; et al. Gaussian 09, Revision A.02; Gaussian, Inc.: Wallingford, CT, USA, 2016.

88. Vardhaman, A.K.; Sastri, C.V.; Kumar, D.; de Visser, S.P. Nonheme ferric hydroperoxo intermediates are efficient oxidants of bromide oxidation. Chem. Commun. 2011, 47, 11044-11046. [CrossRef] [PubMed]

89. Vardhaman, A.K.; Barman, P.; Kumar, S.; Sastri, C.V.; Kumar, D.; de Visser, S.P. Comparison of the reactivity of nonheme iron(IV)-oxo versus iron(IV)-imido complexes: Which is the better oxidant? Angew. Chem. Int. Ed. 2013, 52, 12288-12292. [CrossRef] [PubMed]

90. Hernández-Ortega, A.; Quesne, M.G.; Bui, S.; Heyes, D.J.; Steiner, R.A.; Scrutton, N.S.; de Visser, S.P. Catalytic mechanism of cofactor-free dioxygenases and how they circumvent spin-forbidden oxygenation of their substrates. J. Am. Chem. Soc. 2015, 137, 7474-7487. [CrossRef] [PubMed]

91. Cantú Reinhard, F.G.; Faponle, A.S.; de Visser, S.P. Substrate sulfoxidation by an iron(IV)-oxo complex: Benchmarking computationally calculated barrier heights to experiment. J. Phys. Chem. A 2016, 120, 9805-9814. [CrossRef] [PubMed]

92. Becke, A.D. Density-functional thermochemistry. III. The role of exact exchange. J. Chem. Phys. 1993, 98, 5648-5652. [CrossRef]

93. Lee, C.; Yang, W.; Parr, R.G. Development of the Colle-Salvetti correlation-energy formula into a functional of the electron density. Phys. Rev. B 1988, 37, 785-789. [CrossRef]

94. Hay, P.J.; Wadt, W.R. Ab initio effective core potentials for molecular calculations. Potentials for the transition metal atoms Sc to Hg. J. Chem. Phys. 1985, 82, 270-272. [CrossRef]

95. Hehre, W.J.; Ditchfield, R.; Pople, J.A. Self-consistent molecular orbital methods. XII. Further extensions of Gaussian-type basis sets for use in molecular orbital studies of organic molecules. J. Chem. Phys. 1972, 56, 2257-2261. [CrossRef]

96. Tomasi, J.; Mennucci, B.; Cammi, R. Quantum mechanical continuum solvation models. Chem. Rev. 2005, 105, 2999-3093. [CrossRef] [PubMed]

(C) 2017 by the authors. Licensee MDPI, Basel, Switzerland. This article is an open access article distributed under the terms and conditions of the Creative Commons Attribution (CC BY) license (http://creativecommons.org/licenses/by/4.0/). 